\author{
Timothy P. O'Malley \\ Notre Dame Center for Liturgy, South Bend \\ ORCID 0000-0001-6322-056X
}

\title{
Liturgiczna poetyka Triduum Paschalnego
}

Doroczny obchód Triduum Paschalnego naznaczony jest kontemplacją kluczowych elementów chrześcijaństwa - tego, co jest „piękniejsze, większe, bardziej

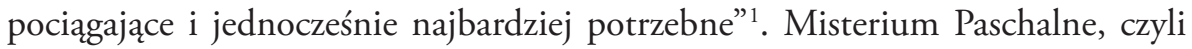
Boża miłość objawiona i aktywnie obecna w życiu, śmierci i zmartwychwstaniu Jezusa Chrystusa, jest przecież teologicznym raison d'etre Kościoła. Kościół nie jest jakimś zgromadzeniem obywateli o podobnych poglądach, schodzących się razem z uwagi na wspólne wartości i opinie o polityce, sztuce, czy nawet o życiu rodzinnym. Nie zbieramy się pod jednym dachem, bo po prostu lubimy spędzać czas jako grupa. Kościół jest raczej komunią wierzących, którą umożliwia zbawienie dane nam w Chrystusie. Kościół jest Oblubienicą Chrystusa, powołaną do istnienia przez jej ukrzyżowanego - i zmartwychwstałego! - Oblubieńca. To Chrystus jest tym, który zwołuje, ba, uwodzi rodzinę ludzką, a my na to zaproszenie odpowiadamy.

W zwykłym roku odpowiadamy na Jego zaproszenie przez udział w liturgiach Triduum. Jesteśmy obecni w czwartkową noc, wyśpiewując raz jeszcze pochwalną ofiarę w Chwata na wysokości, kontemplując dar Ostatniej Wieczerzy, patrząc na umywanie stóp, pozostając na nocną adorację Najświętszego Sakramentu. Przybywamy też w Wielki Piątek, zwracając oczy na zbawienie dokonane przez Cierpiącego Sługę. Przez drzewo krzyża zanosimy modlitwę za całą ludzką rodzinę i adorujemy krzyż pocałunkiem naszych ust. Jednoczymy się w pełnym nadziei żalu, spożywając Ciało Chrystusa. Potem siedzimy w ciszy Wielkiej Soboty, gdy Chrystus zstąpił w kompletną ciemność piekieł. I wreszcie zbieramy się wieczorem w ciemności, by dołączyć do Marii Magdaleny przy grobie naszego Pana. To właśnie w tym sakramentalnym życiu Kościoła zmartwychwstanie ukazuje się hic et nunc (tu i teraz), poprzez chrzest, bierzmowanie i pierwszą komunię neofitów.

1 Papież Franciszek, Adhortacja apostolska Evangelii Gaudium, 35, http://www.vatican.va/content/francesco/pl/apost_exhortations/documents/papa-francesco_esortazione-ap_20131124_ evangelii-gaudium.html (6.04.2020). 
Ale to nie jest zwykły rok. Święte obrzędy wprawdzie będą celebrowane, ale w obecności zaledwie garstki wiernych. Większość z nas będzie zebrana w domach, w postawie „wigilii”, czyli czujności nie tylko wobec zmartwychwstania Pana, ale także wobec zagrożenia zdrowia i życia naszych ukochanych. Może nigdy wcześniej dla naszego pokolenia nie była tak namacalna kruchość ludzkiego życia, ból umierania i to cierpienie, które Chrystus wziął na siebie jako ukrzyżowany Bóg-Człowiek.

Niemniej jednak Triduum będzie świętowane - będzie obchodzone w parafiach, w katedrach i w domowym kościele naszych mieszkań na całym świecie. Chrystus to Oblubieniec, powstały z martwych, i nasze mniej uroczyste celebracje liturgiczne w roku pandemii COVID-19 nie zmieniają tego faktu. Chrystus Pan zmartwychwstał. Prawdziwie zmartwychwstał, nawet jeśli nie ma nas w kościele.

Jednocześnie warto przypatrzeć się liturgii Triduum, gdyż daje ona szansę rozsmakowania się jeszcze bardziej w darze odkupienia, jaki daje nam Pan. Może w te święte dni nie będzie nas w naszych wspólnotach, może nie będziemy w przestrzeni sakralnej naszych parafii, ale liturgiczne śpiewy Wielkiego Czwartku, Piątku i Wigilii Paschalnej wciąż ukazują nam tajemnicę naszego zbawienia. Czerpiąc z poetyki tych śpiewów i hymnów, nie tylko odkryjemy na nowo kluczowe elementy Triduum, ale będziemy pociągnięci, aby wcielić piękno naszego Święta w życie.

\section{Poetyka, liturgia i zbawienie}

Często traktuje się poezję jako zbędną, niekonieczną dla życia człowieka. Jest ona czymś dodatkowym, przesadnym, jest jakąś przeszkodą dla bezpośredniej komunikacji, tak pożądanej z punktu widzenia wydajności. Nawet liderzy Kościoła łatwo wpadają w taki typ myślenia. Programy duszpasterskie ocenia się pozytywnie za bezpośredniość języka, jak też za jakość i liczbę podpunktów opisujących procedurę wdrażania ${ }^{2}$.

Tymczasem jednak, jak przekonuje Karl Rahner w swoim eseju Kaptan i poeta, by mówić o rzeczach fundamentalnych, musimy posłużyć się poetyką inną niż w bezpośredniej konwersacji. Mowa poetycka nie jest dla człowieka nieistotna; to ona właśnie pozwala mu zamieszkać w świecie wypełnionym znaczeniem. Pisze:

Rozkwit, noc, gwiazda i dzień, korzeń i źródło, wiatr i śmiech, róża, krew i ziemia, mały chłopiec, dym, słowo, pocałunek, błyskawica, oddech, cisza: te i tysiące innych słów poważnych myślicieli i poetów są słowami pierwotnymi. Są one głębsze i prawdziwsze niż wytarte słowne monety codziennej

2 Autor pisze z perspektywy Kościoła amerykańskiego, gdzie rzeczywiście pewne standardy wydajności ze świata korporacji zdominowały język duszpasterski diecezji i parafii. 
wymiany intelektualnej, które często nazywa się ,jasnymi ideami”, bo nawyk zwalnia nas z myślenia o czymkolwiek, gdy ich używamy³.

Takie słowa zakorzenione są w fundamentalnym doświadczeniu tego, co to znaczy być człowiekiem. Wschodzące słońce może oczywiście być odbierane jako tylko początek kolejnego dnia pracy, kolejna okazja do uczestnictwa w porządku ekonomicznym świata, jedna z wielu. Ale może też być zrozumiane jako adwent przybycie do nas - nadziei, jako światło, które rozprasza ciemności nocy. Takie podejście jest już językiem tego, co poetyckie, co źródłowe, co pierwotne. Poprzednie odczytanie byłoby dyskursem wieku zanurzonego w technologii i wydajności.

Należy jednak pamiętać, że mowa poetycka nie jest jedynie kontemplacją jakiejś prawdy, która bez niej byłaby nieobecna. Jak przekonuje Rahner, poezja uobecnia owo pierwotne znaczenie, w niej ono przyjmuje ciało poprzez słowo:

(...) to pierwotne słowo jest właściwie ukazaniem samej rzeczy. Nie jest ono tylko znakiem czegoś, czego relacja ze słuchaczem nie ulega zmianie pod jego wpływem; nie mówi tylko „o" relacji omawianego przedmiotu do słuchacza; raczej ono przybliża oznaczaną rzeczywistość do nas, niejako czyni ją „obecną”, sprawia ją i kładzie przed nami. Oczywiście sposób tego uobecniania może być bardzo różny, zależny od rodzaju samej rzeczywistości ewokowanej przez słowo i od mocy ewokującego danego słowa. Niemniej jednak kiedykolwiek takie pierwotne słowo jest wypowiadane, coś się dzieje: nadejście samej tej rzeczy do słuchacza ${ }^{4}$.

Dlatego właśnie postawa osoby słuchającej wobec wiersza jest postawą wyczekiwania, jakby eschatologiczną pozą oczekiwania na przybycie tego, co wiersz objawia czytelnikowi czy słuchaczowi. Kto słucha pieśni 15 z Raju Dantego, nie tylko myśli o smakowitych harmoniach niebiańskich jako o nieco abstrakcyjnej kategorii „rajskiej muzyki”. Nie, słuchacz taki - przez proklamację poematu - staje się obecny (choć w sposób zapośredniczony) w miejscu świętych harmonii nieba i brzemiennej ciszy wizji uszczęśliwiającej:

Benigna volontade in che si liqua

sempre l'amor che drittamente spira,

come cupidità fa ne la iniqua,

3 K. Rahner, Priest and Poet, w: K. Rahner, Theological Investigations, vol. 3, New York 1982, s. 298 (tł. Łukasz Miśko OP).

4 K. Rahner, Priest and Poet, op. cit., s. 298 (tł. Ł. M.). 


\section{silenzio puose a quella dolce lira, e fece quieter la sante corde che la destra cel cielo allenta e tira.}

Ta miłosierna wola, w którą spływa miłość wieczystych ukochań jutrzenki, jak przez niegodną żądza płynie chciwa, wnet uciszyła one słodkie dźwięki lutni niebiańskiej, z której pieśń wybucha lub cichnie na znak Przenajświętszej Ręki 5 .

Przez to przeżycie czytelnik lub słuchacz zaproszony jest do zmiany swego odniesienia do rzeczywistości. Cisza nie ma już być rozumiana wyłącznie jako nieobecność, ale jako nadmiar obecności, jako przedsmak samej wizji uszczęśliwiającej.

Rahnerowskie ujęcie poezji wyjaśnia, dlaczego liturgia tak często mówi w kluczu poetyckim, zamiast po prostu oznajmiać prawdy o zbawieniu czy wyliczać doktryny związane z takim lub innym świętem. Śpiewy te mają naturę performatywną, i to nie tylko dlatego, że śpiewa się je publicznie. Chodzi o to, że w ich proklamacyjnym obwieszczaniu dają uczestnikowi moc, by wszedł on całkowicie w zbawcze wydarzenia. Dlatego też uczestnik musi się również stać wykonawca.

Weźmy na przykład śpiew Chwata na wysokości Bogu wykonywany na początku liturgii Wielkiego Czwartku. Celebrans skuszony dydaktyzmem (a jest takich wielu) mógłby łatwo zastąpić ten hymn żywiołowego uwielbienia prostym stwierdzeniem: Bóg godzien jest naszej chwały, a zatem należy najwyższemu Bogu tę chwałę oddać. Ale nie w ten sposób funkcjonuje Gloria. To właśnie w naddatku uwielbienia, w języku doksologii, który i tak nie może całkowicie uchwycić Boga, Boża chwała staje się obecna. Powtarzamy się kilkakrotnie w tym łacińskim hymnie: „Laudamus Te, benedicimus $\mathrm{Te}$, adoramus $\mathrm{Te}$, glorificamus $\mathrm{Te}$, gratias agimus Tibi propter magnam gloriam Tuam, Domine Deus, Rex caelestis, Deus Pater omnipotens" (Chwalimy Cię, błogosławimy Cię, wielbimy Cię, wysławiamy Cię, dzięki Ci składamy, bo wielka jest chwała Twoja, Panie Boże, Królu nieba, Boże Ojcze wszechmogący). Chwała, błogosławieństwo, uwielbienie, wysławianie, dziękczynienie - ofiarujemy Bogu to wszystko, nawet jeśli są to synonimy. Nasze wyliczanie czynności wobec Boga w tym hymnie pochwalnym nie jest jedynie repetycją jednoznaczności, ale wielogłosem określeń. Wstępowanie w obecność Trójjedynego Boga jest samo w sobie zadaniem poetyckim, a Chwata

5 Dante Alighieri, Boska komedia, cz. 3: Raj, 15:1-6, przeł. A. Świderska, Kęty 2001, s. 463. 
na wysokości to właśnie zadanie wypełnia. $\mathrm{Z}$ tego też powodu należy unikać banalnych aranżacji tego hymnu, wyjaławiających poetykę tekstu. Chwata nie jest przecież jakimś muzycznym przerywnikiem w poważnym procesie pouczania ludu o Jezusie Chrystusie - ten śpiew jest raczej tym, co umożliwia wstąpienie w Jego Boską chwałę.

Uwaga przywiązywana do języka i warstwy muzycznej utworów liturgicznych nie jest zatem zaledwie przyjemniejszą formą zajmowania się teologią. Nie, ta poezja wykorzystana w liturgii staje się dla nas środkiem, poprzez który wchodzimy w wydarzenia naszego odkupienia, w obecność Trójjedynego Boga.

W czasie tego Triduum, gdy nie możemy uczestniczyć w liturgii w naszych kościołach, te właśnie śpiewy mogą stać się integralną częścią celebracji naszej liturgii domowej.

\section{Dar komunii - liturgiczna poetyka hymnu Ubi caritas}

W Wielki Czwartek po homilii celebrans umywa stopy dwunastu członków liturgicznego zgromadzenia. Po tym obrzędzie, podczas procesji z darami, zalecany jest śpiew starego łacińskiego hymnu Ubi caritas ${ }^{6}$. Tu jego oryginalny tekst:

Ubi caritas et amor, Deus ibi est.

Congregavit nos in unum Christi amor.

Exsultemus, et in ipso jucundemur.

Timeamus, et amemus Deum vivum.

Et ex corde diligamus nos sincero. Ubi caritas...

Simul ergo cum in unum congregamur:

Ne nos mente dividamur, caveamus.

Cessent iurgia maligna, cessent lites.

Et in medio nostri sit Christus Deus. Ubi caritas...

Simul quoque cum beatis videamus,

Glorianter vultum tuum, Christe Deus:

Gaudium quod est immensum, atque probum,

Saecula per infinita saeculorum. Amen.

6 Więcej o historii tego hymnu pisze Stanisław Nowak OP w serwisie: https://www.liturgia. $\mathrm{pl} / \mathrm{ubi}$-caritas-et-amor/(6.04.2020). 
Gdzie miłość wzajemna i dobroć, tam znajdziesz Boga żywego.

W jedno nas tu zgromadziła miłość Chrystusa, weselmy się w Nim i radujmy!

Z pokorą szczerą miłujmy Boga, z czystego serca miłujmy się nawzajem.

Skoro się wszyscy tu gromadzimy, strzeżmy się tego, co nas rozdziela.

Niech ustaną wszystkie gniewy i spory, a pośrodku nas niech będzie Chrystus.

Obyśmy oglądali Twoje oblicze, Chryste, Boże, razem ze świętymi w chwale Twego Królestwa. To będzie naszą radością czystą i bez granic, przez nieskończone wieki wieków. Amen.

Ten liturgiczny hymn rozgrywa się pomiędzy poetyką obecności a nieobecności. Stwierdza on z głębokim przekonaniem, że tam, gdzie jest miłość, tam jest Bóg. Tam, gdzie jest Bóg, tam też jest miłość. Jednakże ten rodzaj obecności domaga się ludzkiej odpowiedzi nie w postaci poufałości, lecz raczej w postaci nabożeństwa pełnego zadziwienia, pełnego pokornej i drżącej radości przed obliczem Boga. Widzieliśmy, jak kapłan umywa stopy wiernym, a teraz ten hymn objawia znaczenie tego gestu. To dla nas okazja do uświadomienia sobie, że to miłość Chrystusa miłość do końca, ofiara krzyżowa - stworzyła Kościół. Nasza jedność w komunii jest możliwa, bo to Bóg nas pierwszy ukochał.

Obecność ta nie lekceważy jednak ciemności, jaka mogła ogarnąć zgromadzonych, tego ciągłego przyciągania do ludzkiej grzeszności. W zgromadzonym Kościele może istnieć podział, różnica zdań, nienawiść, agresja - ta ciemność, którą Chrystus jako Światłość świata przyszedł rozproszyć. Gdy wspólnota wierzących polega wyłącznie na sobie, na swoich własnych zaletach (a przez to często również na swoich wadach), oddaje ona cześć nie żyjącemu Bogu, ale bożkom danej epoki. A zatem obmycie stóp nie jest tylko jakimś przyjemnym aktem rozpoznania obrazu i podobieństwa Boga w każdym człowieku. Jest ono raczej szansą na uleczenie, na wybawienie. Członkowie zgromadzenia wiernych muszą na nowo nauczyć się patrzeć na siebie nawzajem w prawdziwszy, uczciwszy sposób.

Dzieło spoglądania z miłością na twarz bliźniego, tego, który wraz ze mną został uświęcony krwią Baranka, jest już samo w sobie przygotowaniem do tego, jak będziemy patrzeć w przyszłości. Błogosławieni, tj. wspólnota świętych w niebie, 
to wszak ci, którzy radują się najpełniej oglądaniem twarzy Chrystusa-Boga. Doświadczają wypełnienia radością tego bezkresu, który jest najwyższym powołaniem człowieka włączonego przez chrzest w Chrystusa.

W tym sensie obmycie stóp ma głębsze znaczenie niż tylko odegranie czegoś, co Jezus kiedyś zrobił w Wieczerniku. Jest ono uobecnieniem, jak sam hymn pokazuje, tej Chrystusowej miłości, która jest samym początkiem i powodem istnienia Kościoła. Oznacza to, że nawet jeśli nie jesteśmy obecni na Mszy Wielkiego Czwartku, to i tak z konieczności pozostajemy obecni dla siebie nawzajem. Przecież być chrześcijaninem, należeć do świętego Kościoła katolickiego to być nierozerwalnie połączonym z naszym bliźnim. Jesteśmy związani więzią miłości, więzią caritas uprzednią wobec nas samych.

Zadaniem Wielkiego Czwartku jest zatem nie tylko pamięć o Ostatniej Wieczerzy, ale również - przede wszystkim - dostrojenie nas do całkowitej, wydającej siebie miłości Chrystusa, która jest obecna w Kościele. Gdy stajemy się wyćwiczeni w tej miłości, w tym spojrzeniu, wtedy też stopniowo uświadamiamy sobie ikoniczną obecność Chrystusa pośród nas.

\section{Mitosierdzie Drzewa: liturgiczna poetyka hymnu Pange lingua}

Pange, lingua, gloriosi

proelium certaminis, et super Crucis trophaeo

dic triumphum nobilem, qualiter Redemptor orbis immolatus vicerit.

Sław, języku, bój chwalebny,

Dzieje walki niezrównanej,

I opiewaj triumf krzyża

Hymnem pełnym uwielbienia,

$\mathrm{Na}$ nim bowiem Odkupiciel

Był zabity, lecz zwyciężył.

De parentis protoplasti

fraude Factor condolens,

quando pomi noxialis

morte morsu corruit,

ipse lignum tunc notavit, damna ligni ut solveret... 
Gdy praojciec zbuntowany

Wziął w swe usta zgubny owoc,

Uległ śmierci w nim ukrytej;

Wtedy Stwórca się zmiłował

Wybierając nowe drzewo,

By dawnego zniszczyć skutki...

Vagit infans inter arcta

conditus praesepia:

membra pannis involuta

Virgo Mater alligat:

et manus pedesque et crura

stricta cingit fascia.

Płacze Dziecię położone

Do ciasnego żłobu w stajni;

Członki owinięte w płótno

Czysta matka przewiązuje:

Ręce, stopy oraz nogi

Skrępowane pieluszkami.

Lustra sex qui iam peracta

tempus implens corporis,

se volente, natus ad hoc,

passioni deditus,

Agnus in crucis levatur

immolandus stipite.

On, przeżywszy między nami

Jako człowiek lat trzydzieści,

Z własnej woli przyjął mękę;

Wypełniając zbawcze dzieło

Na krzyżowej zawisł belce

Jak baranek przebłagalny.

En acetum, fel, arundo,

sputa, clavi, lancea:

mite corpus perforatur, 
Sanguis, unda profluit

terra, pontus, astra, mundus,

quo lavantur flumine!...

Oto znaki Bożej męki:

Żółć, plwociny, trzcina, ocet,

Gwoździe i żelazna włócznia,

Która święty bok przebiła;

Płyną z rany krew i woda,

Aby obmyć wszechświat cały.

Crux fidelis, inter omnes

arbor una nobilis;

nulla talem silva profert,

flore, fronde, germine.

Dulce lignum, dulci clavo,

dulce pondus sustinens!

Krzyżu wierny i szlachetny,

Spośród wszystkich drzew wybrany,

Żaden las nie zrodził drzewa

Piękniejszego ponad ciebie;

Słodkie belki, słodkie gwoździe,

Co dźwigają ciężar słodki!

Flecte ramos, arbor alta,

tensa laxa viscera,

et rigor lentescat ille,

quem dedit nativitas,

ut superni membra Regis

miti tendas stipite.

Schyl gałęzie, drzewo wzniosłe,

Ulżyj członkom tak napiętym;

Niechże zmięknie pień twój twardy,

Aby na nim ciało Zbawcy

I najwyższej chwały Króla

Nie doznało udręczenia! 
Sola digna tu fuisti

ferre saeculi pretium,

atque portum praeparare

nauta mundo naufrago,

quem sacer cruor perunxit,

fusus Agni corpore.

Tylko tyś jest godne przyjąć

$\mathrm{Na}$ ramiona okup ziemi

I ukazać port bezpieczny

Dla tonących w wirach świata,

Ciebie bowiem krew Baranka

Uświęciła swą czerwienią?

Wielu z nas zna ułożony przez św. Tomasza z Akwinu hymn Staw, języku, tajemnicę, śpiewany m.in. w uroczystość Bożego Ciała. Tymczasem kompozycja Tomasza inspirowana była dawniejszym hymnem, napisanym przez Fortunata w VI wieku. Hymn ten należy śpiewać w liturgii podczas adoracji krzyża. Pojedynczy krzyż, być może zawierający relikwie drzewa Krzyża, jest przynoszony przed zgromadzenie. Wierni podchodzą uczcić krzyż, a w tym czasie wykonywane są dwa hymny ${ }^{8}$.

Pierwszy z nich to tzw. Improperia (pol. $L u d u$ mój, ludu), poruszający poemat, w którym sam Jezus zwraca się do zgromadzenia. Ten Bóg, który biczami plag skarał Egipt podczas pierwszej Paschy, teraz sam jest biczowany w drodze na krzyż. Ten Bóg, który zlał mannę jak deszcz z nieba, sam teraz zlany krwią od uderzeń batów i biczy. Ten, który wywyższył swój Lud wielką mocą, wybierając nas spośród wszystkich narodów, jest teraz wywyższony... na krzyżu. Refrenem tego hymnu jest okrzyk: „Ludu mój, co ci uczyniłem? Czym cię zasmuciłem? Odpowiedz mi!"”.

Jednocześnie jednak krzyż zostaje rozpoznany nie tylko jako narzędzie śmierci, ale jako źródło zbawienia. Trisagion, starożytny grecki hymn uwielbienia Boga,

7 Polskie tłumaczenie: P. Galiński OSB, za: Muza chrześcijańska, t. 2: Poezja starożytna i średniowieczna, wstęp, red. i oprac. M. Starowieyski, przekł. Z. Abramowiczówna i in., Kraków, 1992, s. 148-150.

8 Mszał rzymski zatwierdzony dla diecezji w USA zaleca najpierw śpiew antyfony Crucem tuam adoramus (Wielbimy krzyż Twój), potem śpiew Improperia, następnie zaś hymn Pange lingua.

9 Łaciński oryginał: „Popule meus, quid feci tibi? Aut in quo contristavi te? Responde mihi”. Polskie tłumaczenie (za Mioduszewskim, 1838): „Ludu mój, ludu, cóżem ci uczynił? W czemem zasmucił albo w czem zawinił?" 
przerywa ten poemat liryczny. Jak chór w antycznej tragedii, interpretujący dla widza rozwijającą się akcję dramatu, słyszymy tu w Improperia: „Hagios o Theos, Hagios Ischyros, Hagios Athanatos, eleison himas" (Święty Boże, święty mocny, święty nieśmiertelny, zmiłuj się nad nami ${ }^{10}$.

Po śpiewie Improperia następuje hymn Fortunata, Pange lingua ${ }^{11}$. Jest w tym hymnie swoista samoświadomość. Fortunat mówi nam od samego początku, że chce ułożyć hymn o zwycięstwie czy „tryumfie” Krzyża. Bitwa została wygrana, co jest uwidocznione w geście ucałowania tego świętego trofeum przez zgromadzenie. Dalej Fortunat wyjaśnia nam tę miłosierną logikę drzewa. Pierwszy grzech naszych praojców polegał na zawłaszczeniu sobie owocu z drzewa poznania dobra i zła. Owoc ten był szkodliwy, zatruty, i wprowadził do świata tę agresję, która doprowadziła później do ukrzyżowania Jezusa. A jednak Bóg miał w swoich planach inne drzewo, inny owoc - taki, który uleczy rodzinę ludzi.

Ogołocenie we wcieleniu - oto korzeń tego nowego drzewa. Bóg-człowiek, Jezus Chrystus, narodził się, by cierpieć. Przy swoim narodzeniu został owinięty w pieluszki, obraz tych płócien, w które będzie owinięte Jego ciało w grobie. Chrystus na to się narodził, na ten moment cierpienia na krzyżu. Odczuwał głód i pragnienie w pustyni, płakał nad grobem Łazarza, bo przyszedł po to, żeby przyjąć na siebie całość ludzkiej kondycji.

Ta właśnie ludzka kondycja, w całej swej agresywności, jest widoczna w ukrzyżowaniu. Ciało Pana ocieka krwią, jest dziurawione gwoźdźmi i włócznią. Krew i woda, które wypływają z Jego boku, nie są czymś delikatnym, lecz gwałtownym potokiem. Cały świat odnawia się w tym obmyciu, w tej rzece miłości płynącej z boku Chrystusa.

Ale hymn na tym się nie kończy! Jak w Improperiach, tak i tu jest jeszcze inny głos, który teraz przemawia. To nie głos nieobecnego narratora, oznajmiającego tylko to, co się stało. To głos każdego z nas, wołający do drzewa krzyża o miłosierdzie. Ten krzyż, jak się okazuje, jest drzewem życia z Księgi Rodzaju. To jest to drzewo, które Bóg obiecał ludzkości od początku.

Wołamy do tego drzewa, do tego zwycięstwa, do tego trofeum, by delikatnie potraktowało ciało naszego Króla. Nie rozciągaj Jego ciała, łamiąc je boleśnie, lecz zegnij się, o drzewo, w akcie miłosierdzia. Wiemy, że to jest nasze zbawienie, wiemy, że to jest ta tajemnica ukryta od wieków, od założenia świata, lecz jednak to nasz Brat, On jest nasz.

10 W polskim przekładzie Mszału rzymskiego śpiew Trisagionu jest zasugerowany tylko przed Ludu mój, ludu, nie jako refren (przyp. tł.).

11 Polski przekład Mszału rzymskiego proponuje tylko zwrotki 8-10, uzupełnione 4 zwrotkami polskiej pieśni pasyjnej Krzyżu Święty. 
Przed końcem hymnu drzewo zostaje przemienione. Staje się trofeum zbawienia, uświęcone krwią Baranka. To drzewo jest wrzucone w ocean rozpaczy, by uratować tonącą ludzkość. To drzewo jest uniesione wysoko tak, by każdy je zobaczył.

Jednakże nie jest to koniec liturgii. Teraz następuje liturgia uprzednio poświęconych darów, liturgia eucharystycznego chleba zakonsekrowanego wczoraj, w której w ten dzień postu posilamy się Ciałem Chrystusa. Krzyż bowiem wydał najsłodszy ze wszystkich owoców. To właśnie Eucharystia, Ciało Chrystusa, jest owocem drzewa życia. W tym roku, gdy większość z nas pozostanie w domu, nie dane nam będzie spożywać tego owocu. Zgłodniejemy. A może taki głód nie musi być jedynie brakiem? Może, jak św. Bonawentura w jego dziele Drzewo życia, możemy świętować ten owoc. Może warto zakrzyknać:

O, jak cudowne są wszystkie te rzeczy,

Jak pełne słodyczy,

Lecz tylko dla tej duszy,

Która, zostawszy wezwana na tak zaszczytną ucztę,

Biegnie

$\mathrm{Z}$ całą mocą swego ducha

Tak, byśmy wołali z Prorokiem:

„Jak łania pragnie wody ze strumieni,

Moja dusza pragnie Ciebie, Boże" (Ps 41, 2) ${ }^{12}$.

A zatem wpatrujmy się w naszych domach w krzyż Pana, w krzyż Chrystusa. I tęsknijmy za owocem drzewa życia, owocem Jego Ciała, który leczy chorą na grzech duszę ludzkości.

\section{Jest to olśniewająca noc: liturgiczna poetyka Exsultetu}

Exsúltet iam angélica turba calórum:

exsúltent divina mystéria:

et pro tanti Regis victória tuba insonet salutáris...

Weselcie się już, zastępy Aniołów, w niebie:

weselcie się, słudzy Boga.

Niechaj zabrzmią dzwony głoszące zbawienie, gdy Król tak wielki odnosi zwycięstwo.

12 Sw. Bonawentura, The Tree of Life, 16, w: Bonaventure, trans. E. Cousins, New York 1978 (tł. $\mathrm{z}$ ang. Ł. M.). 
Raduj się, ziemio, opromieniona tak niezmiernym blaskiem, a oświecona jasnością Króla wieków, poczuj, że wolna jesteś od mroku, co świat okrywa!

Zdobny blaskiem takiej światłości, raduj się, Kościele święty, Matko nasza! Ta zaś świątynia niechaj zabrzmi potężnym śpiewem całego ludu. (...)

Jest to ta sama noc, w której niegdyś ojców naszych, synów Izraela, wywiodłeś z Egiptu i przeprowadziłeś suchą nogą przez Morze Czerwone.

Jest to zatem ta noc, która światłem ognistego słupa rozproszyła ciemności grzechu, a teraz ta sama noc uwalnia wszystkich wierzących w Chrystusa na całej ziemi od zepsucia pogańskiego życia i od mroku grzechów, do łaski przywraca i gromadzi w społeczności świętych.

Tej właśnie nocy

Chrystus skruszywszy więzy śmierci, jako zwycięzca wyszedł z otchłani.

Nic by nam przecież nie przyszło z daru życia, gdybyśmy nie zostali odkupieni.

O, jak przedziwna łaskawość Twej dobroci dla nas!

O, jak niepojęta jest Twoja miłość:

aby wykupić niewolnika, wydałeś swego Syna.

O, zaiste konieczny był grzech Adama, który został zgładzony śmiercią Chrystusa! O, szczęśliwa wina, skoro ją zgładził tak wielki Odkupiciel!

O, zaiste błogosławiona noc, jedyna, która była godna poznać czas i godzinę zmartwychwstania Chrystusa. O tej to nocy napisano: a noc jako dzień zajaśnieje, oraz: noc będzie mi światłem i radością.

Uświęcająca siła tej nocy oddala zbrodnie, z przewin obmywa, 
przywraca niewinność upadłym, a radość smutnym, rozprasza nienawiść, usposabia do zgody i ugina potęgi.

W tę noc pełną łaski przyjmij, Ojcze Święty, wieczorną ofiarę uwielbienia, którą Ci składa Kościół święty, uroczyście ofiarując przez ręce swoich sług tę świecę, owoc pracy pszczelego roju.

Znamy już wymowę tej woskowej kolumny, którą na chwałę Boga zapalił jasny płomień. Chociaż dzieli się on, użyczając światła, nie doznaje jednak uszczerbku, żywi się bowiem strugami wosku, który dla utworzenia tej cennej pochodni wydała pracowita pszczoła.

O, zaiste błogosławiona noc, w której się łączy niebo z ziemią, sprawy boskie ze sprawami ludzkimi.

Prosimy Cię przeto, Panie, niech ta świeca poświęcona na chwałę Twojego imienia nieustannie płonie, aby rozproszyć mrok tej nocy.

Przyjęta przez Ciebie jako woń przyjemna, niechaj się złączy ze światłami nieba.

Niech ta świeca płonie, gdy wzejdzie słońce nie znające zachodu: Jezus Chrystus, Twój Syn Zmartwychwstały, który oświeca ludzkość swoim światłem i z Tobą żyje i króluje na wieki wieków. Amen ${ }^{13}$.

Exsultet to śpiew wykonywany po zapaleniu Paschału. To bardzo dawny utwór, ułożony najprawdopodobniej między V a VII wiekiem. Śpiewany przez diako$\mathrm{na}^{14}$, ma układ błogosławieństwa podobnego w strukturze do modlitw używanych w liturgii Eucharystii. Pamiętając miłosierne czyny Boga z przeszłości, radosnym sercem wyczekujemy dobra, jakiego Bóg dokona w naszej teraźniejszości.

13 Mszat rzymski dla diecezji polskich, Poznań 2013, s. 155-161.

${ }_{14}$ A w razie jego nieobecności przez prezbitera lub świeckiego kantora (przyp. tł.). 
Poezja Exsultetu jest nierozdzielnie związana z rytuałem, który wydarza się wokół niego. Lud gromadzi się przed kościołem, już po zachodzie słońca. Jedyne dostępne źródło światła to płonący ogień, cały budynek kościelny otulony jest ciemnością. Na początku Wigilii Paschalnej mamy tylko podstawowe, pierwotne elementy: światło i ciemność, płomień i świeca, wiatr i gwiaździste niebo nad nami. Tymczasem ta zrobiona z wosku świeca zostanie przekształcona poprzez działanie Kościoła: zostanie naznaczona znakiem krzyża, wzbogacona kadzidłem w kształcie pięciu ran Chrystusa. Ta świeca powiedzie ludzi zagubionych w ciemności do przedziwnego światła zbawienia.

Tekst tego hymnu opisuje kosmiczną transformację nie tylko świecy, ale całej materii, przez zmartwychwstanie Jezusa Chrystusa. Ten kosmiczny wymiar uwielbienia rozpoczyna się od zastępów aniołów w niebie, a kończy na zgromadzonym ludzie, na Kościele, który istnieje po to, by wielbić. Świeca jest częścią okazji do tej pochwały, bo to ona rozjaśniła ciemności naszej świątyni, pogrążonej w mroku od momentu śmierci Pana w Wielki Piątek. Ale to nie jest tylko zwykła świeca, to nie jest zwyczajna noc.

W trakcie śpiewu Exsultetu często powtarza się refren: „heac est nox”, „jest to ta noc". Exsultet zakłada tu jakby zgodność kalendarza. Ta noc jest nocą wszystkich nocy, ta noc olśniewa, jest pełna radości. Tej bowiem nocy Izrael został uratowany od niewoli w Egipcie. Tej nocy lud Izraela wędrował przez pustynię, oświetlony słupem obłoku. I tej właśnie nocy Chrystus powstał z martwych.

Łacina użyta w hymnie opisuje zbawienie, dokonane przez Chrystusa, używając terminologii pochodzącej z ekonomii. Nasze narodziny byłyby bezwartościowe, gdyby Chrystus nie odkupił ludzkości przez swoją śmierć i zmartwychwstanie. Ale kupno to przekracza granice ekonomii, czystej wymiany, granice do ut des, daję abyś ty mógł dać. Przekracza je, bowiem Ojciec okazał niewymierną miłość, łaskawość bez miary, w akcie wydania Syna jako zapłaty za dług grzechu.

Exsultet domaga się poważnego potraktowania tego długu. Jeśli nie rozpoznamy konsekwencji grzechu i śmierci, czyli tego, o co tak naprawdę chodzi w zmartwychwstaniu, to nie zrozumiemy, co czyni tę noc tak cudowną. To właśnie czysta szczodrość miłości, która jest jakby przesadna, ponad miarę, hojna miłość, która wcale nie musiała dawać, lecz dała. Wejście tej miłości w nasze życie zmusza nas to nowego spojrzenia na całą historię. Grzech Adama jest teraz szczęśliwą winą (felix culpa), bo „zasłużyła” na hojność Odkupiciela, zaiste działającego według jakiejś absurdalnej, szaleńczej ekonomii ${ }^{15}$.

15 Łaciński oryginał mówi o tym, że szczęśliwa wina Adama zasłużyła (méruit) na tak wielkiego Zbawiciela: „O felix culpa, quæ talem ac tantum méruit habére Redemptórem!”. Niestety, 
Istotnie, sama noc doznała przemiany w tym procesie odkupienia. Po ludzku myśląc, noc jest czasem na strach. To czas ciemności, czas tego, co nieznane, czas inwazji koszmarów. Po Ostatniej Wieczerzy Judasz porzucił towarzystwo apostołów, by sprzedać Jezusa władzom. W Ewangelii Janowej, po jego wyjściu, autor wspomina porę dnia: jak czytamy w Wulgacie, „erat autem nox” („a była noc” J 13, 30). Judasz wyszedł w ciemność rozpaczy, do cienia rebelii.

Teraz noc nie jest już czasem strachu. Noc jest „zaiste błogosławiona”, bo jako jedyna „widziała” ${ }^{16}$ zmartwychwstanie. Ciemność nie jest już czymś, czego mamy się lękać, bo i ona sama została odkupiona przez śmierć i zmartwychwstanie Jezusa Chrystusa.

A zatem świeca jest symbolem, ba!, samą obecnością Chrystusa, który odkupuje ciemność. Światło rozbłysło w ciemności, rozpraszając cienie świata grzechu i śmierci, a dar życia ofiarowany nam przez tę świecę staje się równocześnie obecnością tej hojnej miłości, tego cudownego zjednoczenia Boga i człowieka w Jezusie Chrystusie. Jak pisze o świecy Romano Guardini:

Przypatrz się, jak świeca osadzona jest w świeczniku. Szeroko i masywnie rozparła się podstawa, z której bezpiecznie wznosi się trzon świecznika, powyżej zaś wystrzela świeca... smukła, w niepokalanej czystości, a przecież ciepło stonowana w swym kolorze: przez jasny swój kształt wyróżniająca się z wszelkiego chaosu. Ponad nią chwieje się płomyk, a przezeń świeca czyste swe ciało przemienia w ciepłe, promienne światło. Czy wobec niej nie budzi się w Tobie jakieś niezmiernie szlachetne uczucie? Spójrz, jak ona stoi niezachwianie w jednym miejscu, wyprostowana na całą wysokość, czysta i dostojna. Zważ, jak wszystko w niej mówi: „Jestem gotowa!”. Jak ona stoi wytrwale tam, gdzie stać jej nakazano, przed Bogiem ${ }^{17}$.

Świeca to obraz całego stworzenia, owoc pracy pszczół i pracy ludzkich rąk. Stworzenia, a zatem i ludzka historia, stają się niejako konsekrowane poprzez błogosławieństwo tej świecy. Słodycz wosku, światło, które tu jest stwarzane, oddane są kompletnie Bogu. Unoszący się ku niebu dym uosabia owo całkowite oddanie, dar miłości, jaki Kościół ofiarowuje w odpowiedzi Bogu, który pierwszy ukochał ludzką rodzinę.

oficjalne polskie tłumaczenie upraszcza to zdanie: „O, szczęśliwa wina, skoro ją zgładził tak wielki Odkupiciel!”.

16 Łac.: O vere beáta nox, quæ sola méruit scire tempus et horam, in qua Christus ab ínferis resurréxit! Polskie tłumaczenie Exsultetu ma: „jedyna, która byłaś godna poznać czas...”

17 R. Guardini, Znaki święte, przeł. J. Birkenmajer, Wrocław 1982, s. 45-46. 
A zatem staje się świeca nastaniem uczty weselnej. To, co ludzkie, zostaje związane z tym, co boskie, to, co boskie, jest teraz zjednoczone ze sprawami ludzkimi. Wszystko w tę noc, w tę błogosławioną noc, może być poświęcone Bogu. Dalszy ciąg Wigilii Paschalnej jasno to pokazuje: woda, chleb i wino, ludzkie ciało wszystko zostaje uświęcone, „konsekrowane” dla Boga ${ }^{18}$.

Być może radość tej totalnej konsekracji, tej wcielonej ofiary, to właśnie to, co czyni naszą Wielkanoc z dala od kościoła tak trudnym doświadczeniem. Wielkanoc przecież to nie tylko okazja do pobożnego upamiętniania zmartwychwstania Pana. Ona jest fundamentem całego życia Kościoła - sakramentalnego systemu, w którym to, co materialne, staje się teraz środkiem naszego odkupienia. Sprawy ludzkie zaślubione sprawom boskim... Nie będzie nas w tym roku na błogosławieństwie paschalnego światła, ale zmartwychwstanie wydarza się i tak. Stworzenie się przemienia, bo Bóg-Człowiek odkupił rodzaj ludzki. Noc nie jest już dla strachu, lecz dla wigilijnego czuwania w Bożej obecności.

Wciąż jednak czuwanie wymaga szczególnego rodzaju cierpliwości. Nasza świeca może być symbolem tej Gwiazdy Porannej, tego Słońca nieznającego zachodu, lecz ona sama wypali się i odejdzie w niepamięć. Ostatnia kropla wosku spadnie z błogosławionej świecy. Również my, ludzie, musimy umrzeć. Opadnie na nas ciemna zasłona śmierci. Lecz my czekamy cierpliwie na hojność Boga, który daje więcej niż jesteśmy w stanie dostrzec. Jak pisze Jean-Yves Lacoste w swojej filozoficznej narracji Wigilii:

(...) między Bogiem i nami, świat pozostaje tym, czego nie możemy opuścić, ani uchylić. Należy zatem zrozumieć, że zrzekamy się cierpliwie wszelkiej pretensji do bycia nieodwołalnie panami dzieła i powierzamy je Bogu jako dawcy tego, co nie przemija. Jesteśmy wolni, by się wystawić na przejście Absolutu. Jesteśmy wolni, by Mu ofiarować naszą gościnę. Ale z jednej strony ta gościna może być przyjęta bez naszej wiedzy, a z drugiej - historia trzyma nas z dala od odwrócenia eschatologicznego, kiedy Absolut zaofiaruje nam gościnę ostateczną. Trzeba zatem cierpliwie dawać nasz czas ${ }^{19}$.

Wigilia liturgiczna, włącznie ze śpiewem Exsultetu, nie jest ucieczką przed kondycją człowieka. Zmartwychwstanie nie znaczy, że nie musimy już cierpliwie czekać przed grobem. Raczej oznacza ono, że ta cierpliwość, to pokorne trwanie, wyczekiwanie w mroku przed grobem - że one są sposobem, w jaki już

18 Autor używa tu wieloznacznego słowa „to consecrate”, które może oznaczać zarówno poświęcenie czegoś, jak też uświęcenie, a wreszcie konsekrację w wąskim sensie sakramentalnym. 19 J.-Y. Lacoste, Expérience et Absolu, Paris 1994, s. 113 ( tł. fragmentu: Dominik Jarczewski OP). 
celebrujemy zbawienie, oczekując hojności i łagodnego światła, jakiego żaden człowiek nie ogarnie.

\title{
Konkluzja
}

Wielkanoc, nawet w czasie COVID-19, będzie obchodzona. Fizycznie nie udamy się do naszych kościołów na liturgię. Większość z nas pozostanie schowana w domach, trochę tak jak uczniowie w Wieczerniku. A jednak inaczej niż oni, my mamy dostępną poetykę Świąt. Kontemplując tę poezję, jesteśmy czymś więcej niż estetami, którzy cenią sobie grę słów. My, przez tę kontemplację, przyjmujemy już owoce zmartwychwstania.

\begin{abstract}
Abstrakt
Czy bez dostępu do publicznych celebracji Triduum Sacrum, odwołanych z powodu pandemii roku 2020, jest możliwe duchowe uczestniczenie w tych liturgiach? Esej wykazuje, że kluczowym sposobem udziału w liturgiach, pomimo nieobecności na celebracji, jest medytacja nad poetyckimi tekstami liturgii. Poezja liturgiczna daje możliwość wejścia w historię zbawienia za pośrednictwem słowa śpiewanego. Niniejszy tekst skupia się na trzech poematach liturgicznych Triduum: Ubi caritas z Wielkiego Czwartku, Pange lingua z Wielkiego Piątku oraz Exsultetu z Wigilii Paschalnej. W każdym z tych utworów słowa prowadzą chrześcijanin ku obecności misterium paschalnego Chrystusa, przygotowując ich do radości z duchowych owoców Triduum.
\end{abstract}

Stowa kluczowe: Triduum; Covid-19; Ubi caritas; Pange lingua; Exsultet; Wielkanoc

\section{Abstract}

\section{The Liturgical Poetics of the Triduum}

With the cancellation of the public celebration of the Triduum during the pandemic of 2020, how may Catholics spiritually participate in these liturgies? This essay argues that a key way of participating in liturgies, even when physically absent from the celebra- 
tion itself, is through meditation on the poetic texts of the liturgy. Liturgical poetry offers an entree into salvation history through the mediation of the chanted word. The essay attends to three liturgical poems of the Triduum including the Ubi caritas of Holy Thursday, the Pange lingua of Good Friday, and the Exsultet of the Easter Vigil. In each of these poems, the texts bring the Christian into the presence of Christ's Paschal Mystery, attuning the Christian to enjoy the spiritual fruits of the Triduum.

Keywords: Triduum; Covid-19; poetry; Ubi caritas; Pange lingua; Exsultet; Easter

\section{Bibliografia}

Dante Alighieri, Boska komedia, cz. 3: Raj, przeł. A. Świderska, Kęty 2001.

Guardini R., Znaki święte, przeł. J. Birkenmajer, Wrocław 1982.

Lacoste J.-Y., Expérience et Absolu, Paris 1994.

Mszat rzymski dla diecezji polskich, Poznań 2013.

Muza chrześcijańska, t. 2: Poezja starożytna i średniowieczna, wstęp, red. i oprac. M. Starowieyski, przekł. Z. Abramowiczówna i in., Kraków 1992.

Nowak S. OP, Ubi caritas et amor, https://www.liturgia.pl/ubi-caritas-et-amor/ (6.04.2020).

Papież Franciszek, Adhortacja apostolska Evangelii Gaudium, http://www.vatican.va/ content/francesco/pl/apost_exhortations/documents/papa-francesco_esortazione-ap_20131124_evangelii-gaudium.html (6.04.2020).

Rahner K., Priest and Poet, w: K. Rahner, Theological Investigations, vol. 3, New York 1982. Św. Bonawentura, The Tree of Life, w: Bonaventure, trans. E. Cousins, New York 1978. 